\title{
Challenges to Water Management in Ecuador: Legal Authorization, Quality Parameters, and Socio-Political Responses
}

\author{
Sarah Wingfield ${ }^{1}$, Andrés Martínez-Moscoso ${ }^{2}$, Diego Quiroga ${ }^{3}$ and Valeria Ochoa-Herrera ${ }^{3,4, *}$ \\ 1 School of Foreign Service, Georgetown University, 3700 O Street NW, Washington, DC 20057, USA; \\ smw272@georgetown.edu \\ 2 Colegio de Jurisprudencia, Instituto de Investigaciones Jurídicas, Universidad San Francisco de Quito, \\ Diego de Robles y Vía Interoceánica, 17-1200-841 Quito, Ecuador; amartinez@usfq.edu.ec \\ 3 Galapagos Science Center, Universidad San Francisco de Quito and University of North Carolina at Chapel \\ Hill, Alsacio Northia Avenue, 200150 Puerto Baquerizo Moreno, Ecuador; dquiroga@usfq.edu.ec \\ 4 Colegio de Ciencias e Ingenierías, Instituto Biósfera, Universidad San Francisco de Quito, \\ Diego de Robles y Vía Interoceánica, 17-1200-841 Quito, Ecuador \\ * Correspondence: vochoa@usfq.edu.ec
}

check for updates

Citation: Wingfield, S.; Martínez-Moscoso, A.; Quiroga, D.; Ochoa-Herrera, V. Challenges to Water Management in Ecuador: Legal Authorization, Quality Parameters, and Socio-Political Responses. Water 2021, 13, 1017. https://doi.org/ 10.3390/w13081017

Academic Editors: Bruce M. Wilson and Athanasions Loukas

Received: 26 February 2021

Accepted: 31 March 2021

Published: 8 April 2021

Publisher's Note: MDPI stays neutral with regard to jurisdictional claims in published maps and institutional affiliations.

Copyright: (c) 2021 by the authors. Licensee MDPI, Basel, Switzerland. This article is an open access article distributed under the terms and conditions of the Creative Commons Attribution (CC BY) license (https:// creativecommons.org/licenses/by/ $4.0 /)$.

\begin{abstract}
Ecuador has historically had a unique experience with water law, management, and policy as a result of its constitutional declaration of water access as a human right. In this paper, the legal, environmental, economic, and social aspects related to water management in Ecuador are analyzed. In doing so, the incorporation of local governance structures such as water users' associations (WUAs) are characterized within a national model of authorization under SENAGUA, Ecuador's former water agency, highlighting the importance of integrated management for meeting the country's geographically and environmentally diverse needs. Additionally, the role of anthropogenic activities such as crude oil production, artisanal and small-scale gold (ASGM) mining, agriculture, sewage discharge, and domestic practices are evaluated in the context of policy implementation and environmental quality concerns. Finally, individual and community-level responses are explored, highlighting the importance of geographically specific perceptions of water rights and quality in the adoption of coping strategies. In these ways, a multi-faceted analysis of Ecuadorian water policy shaped by community-level engagement, geographic diversity, and influential economic sectors is developed. This study highlights the need for increased financial and legislative support around extractive and polluting industries such as agriculture, ASGM, and sewage treatment for long-term safety and sustainability of water access in Ecuador. Additionally, increased efforts to educate industry-specific workers, local management boards, and individuals about potential solutions to water-related challenges will help improve the efficiency of current legislation. Finally, this study underscores a need for additional research related to water quality and sustainability in Ecuador, as well as for the social, economic, and environmentally specific factors that influence water security outcomes in the country.
\end{abstract}

Keywords: water management; legal authorization; environmental; economic; socio-political responses

\section{Introduction}

The adoption of United Nations Sustainable Development Goal 6 has spurred efforts for water and sanitation access in low and middle-income countries (LMICs) at a global scale [1]. At the onset of the COVID-19 pandemic, the importance of reliable and secure water access for overall health was made evident by the disparities between the impacts on low- versus high-income communities with differing levels of access to sanitation resources [1].

In the last century, most water management research has included independent visions of legal, environmental, economic and social issues; consequently, its analysis does 
not constitute an integrated perspective. A multidisciplinary focus provides a deeper understanding of water management problems by viewing individual components of water management as interconnected. It is for this reason that several governments have created an institutionalism around water, comprised of a Water Authority (Secretary or Ministry), an independent water law, environmental quality requirements, and, in some cases, a recognition of water as a human right [2].

At a global level, numerous countries have expressed preoccupation about water management, driving the regular creation of international treaties and declarations by the United Nations [3] and other regional organizations since the 1970s. Moreover, thematic conventions have frequently emphasized the relationship between women [4], children [5], sustainable development [6], and water. Since 2002, the United Nations has focused on improving water access and quality conditions throughout the world, beginning with the General Comment No. 15: The Right to Water, of the Office of the High Commissioner for Human Rights [7]. By 2010, the Resolution 64/292 of the Human Right to Water and Sanitation was adopted by the General Assembly, along with the creation of the Special Rapporteur on the Human Right to Safe Drinking Water and Sanitation.

In Ecuador, water law is distinguished by the declaration of water access as a constitutional right and presence of critical environmental sites such as the Galapagos Islands and the Amazon [8-10]. Recent changes to water policy, in addition to increasing influence of disruptive anthropogenic activities (such as oil, mining, agriculture, and sewage discharge, among others) have resulted in the development of a dynamic and culturally specific framework for water management in Ecuador [11-13]. Moreover, the incorporation of community management systems into the national framework has afforded rural and isolated regions a greater voice in policy development under the Ministerio del Ambiente y Agua [14]. In addition, the persistent challenges of untreated sewage discharge, ASGM mining activity, and crude oil extraction have become critical to understanding water safety in Ecuador [15-18]. Finally, perceived inequities and threats of water insecurity have driven a search for alternative resources, new household coping strategies, and, in some cases, socio-political involvement among Ecuadorian residents [19-21].

The Republic of Ecuador is a unitary country located in the northwest region of South America. Home to approximately 17 million inhabitants, Ecuador's government is characterized by a decentralized administration comprised of 24 provinces and $221 \mathrm{mu}-$ nicipalities [22]. Ecuador's water management system consists of an authorization-based framework in which differing responsibilities are applied to distinct levels of government. For example, while the central government is responsible for the general regulation, control, and management of water at a national level, provincial and local governments are responsible solely for the management of water for irrigation and drinking water resources (respectively). As a result, the management structure presents potential conflicts related to water allocation and use. In addition, a lack of technical and infrastructural capacity at a local level introduces further challenges for water management in the country.

Ecuador's per-capita availability of water resources is triple the international average $(22,929$ cubic meters per person, per year), with an average annual precipitation of $1100 \mathrm{~mm}$ (43.31 in) [23]. In addition, nearly $90 \%$ of the Ecuadorian population has access to safe sanitation and basic handwashing facilities (90.7\% and $89.1 \%$, respectively) [24]. Nevertheless, access to safe, high-quality water resources remains a challenge: only $73.4 \%$ have access to water of standard quality (i.e., without contamination by E. coli) and a mere $67.8 \%$ have access to higher quality and safe drinking water resources [24].

In this paper, an analysis of water management in Ecuador is conducted through a review of legal policies, environmental data, economic frameworks, and social studies related to water access. In doing so, factors such as small-scale gold mining (ASGM), agriculture, sewage treatment practices, water users' associations (WUAs), and culturally specific concepts were evaluated in the context of water management. This study underscores the need for expansion of local regulation, specifically through improved sewage treatment practices, extension of community education programs, and the incorporation 
of local management systems (such as WUAs) into the regulation framework under the Ministerio del Ambiente. Moreover, this study emphasizes the importance of additional research exploring the intersections between water use practices and the long-term stability and safety of water use. By establishing a baseline understanding of the factors influencing allocation outcomes, researchers and decision-makers may improve the long-term security of water resources in Ecuador.

\section{Materials and Methods}

This study is divided into four core sections: legal documentation and policy analysis, environmental impact studies, economic assessments, and socio-political analysis. In Section 3.1, the role of culturally significant concepts such as sumak kawsay and buen vivir and the recent expansion of water users' associations into the regulation framework are explained. In Section 3.2, the impact of anthropogenic activities such as mining, crude oil extraction, and sewage discharge are accessed in the context of environmental and public health. In Section 3.3 and Section 3.4, the influence of these industries on water quality, household adaptation practices, and protest activities is evaluated [20,25].

During the first task, a literature review of available legislative and secondary research documents was conducted to evaluate existing policy surrounding water management in Ecuador. In addition to the review of official government documents such as Texto Unificado de la Legislación Secundaria del Ministerio del Ambiente, or "TULSMA" (TULSMA), Norma Técnica Ecuatoriana del Instituto Ecuatoriano de Normalización (NTE INEN 1108), and the 2008 Constitution, a literature search for peer-reviewed journals was performed in Environment Complete and ScienceDirect. This search yielded 1043 articles, of which the 25 most-relevant articles were reviewed. Next, a literature review of peer-reviewed articles in the same databases was performed to evaluate water and environmental quality parameters in Ecuador. This step yielded 6520 total articles, of which the 30 most salient were reviewed. Following the water quality assessment, a literature search in Environment Complete and ScienceDirect was conducted to analyze water policy and management from an economic perspective, again seeking peer-reviewed journals through key search terms. This search yielded 2242 total peer-reviewed journal articles, of which we reviewed the 16 prominent articles. Finally, the same databases were utilized to identify articles discussing the social aspects of water management in Ecuador, yielding 832 peer-reviewed articles. Of these, the 29 most-relevant articles were reviewed. In these ways, a comprehensive review of the existing literature related to each of the four relevant areas of water management in Ecuador was generated.

\section{Results and Discussion}

\subsection{Water Law and Policy in Ecuador}

\subsubsection{The Ecuadorian Constitution}

The legal state of water management in Ecuador begins with its constitution, which provides specific considerations for water [26]. Until 1960, constitutional regulation allowed for the privatization of water management, viewing it as a commodity rather than a public good [27]. Later, major political changes led to the declaration of water as a national good, first in 1960 and then again in 1972, effectively ending privatization in the country [28]. In the 1990s, however, legislation allowed for private investment in the water sector through "new public management," an idea developed in the 1998 Constitution. By 2008, Ecuador became the first nation to declare water a human right [26]. In doing so, the government incorporated sumak kawsay - an Andean concept which harmonizes human development with environmental protection by recognizing nature as having innate rights-into its goal for buen vivir, through which the living conditions of its citizens would be improved [8,29]. Sumak kawsay, or "good living", was incorporated into the 2008 Constitution to reflect the importance of environmental issues in the construction of an inclusive society, demonstrating a view of resource management that allows human populations to live in harmony with nature. These constitutional changes represent a 
conceptual framework that distinguishes Ecuador's environmental protection policies from those of other nations [8].

3.1.2. Water Law: Ecuador's Governing Law for the Use of Water and Hydrological Resources

Following the 2008 Constitution, Ecuador's emphasis on sustainability and equality was formalized in the Ley Orgánica de Recursos Hídricos, Usos, y Aprovechamiento del Agua (hereafter referred to as "Ley Orgánica"). Under this body of law, water is defined as a national strategic asset and a public resource subject to state regulation [30]. Nevertheless, the law allows for localized management of resources in cases where communities or individuals have financed and constructed the main water infrastructure [30]. Critically, however, the Ley Orgánica stipulates that any communal or indirect management of these resources must be in accordance with state requirements, thereby reserving ultimate authority to the Water Secretary, or the national regulative body of water governance in Ecuador [30].

The Ley Orgánica also establishes a sectionalized system that typifies water allocation into distinct categories according to their use priority. Figure 1 illustrates these categories in the order of their prioritization under the Ley Orgánica.

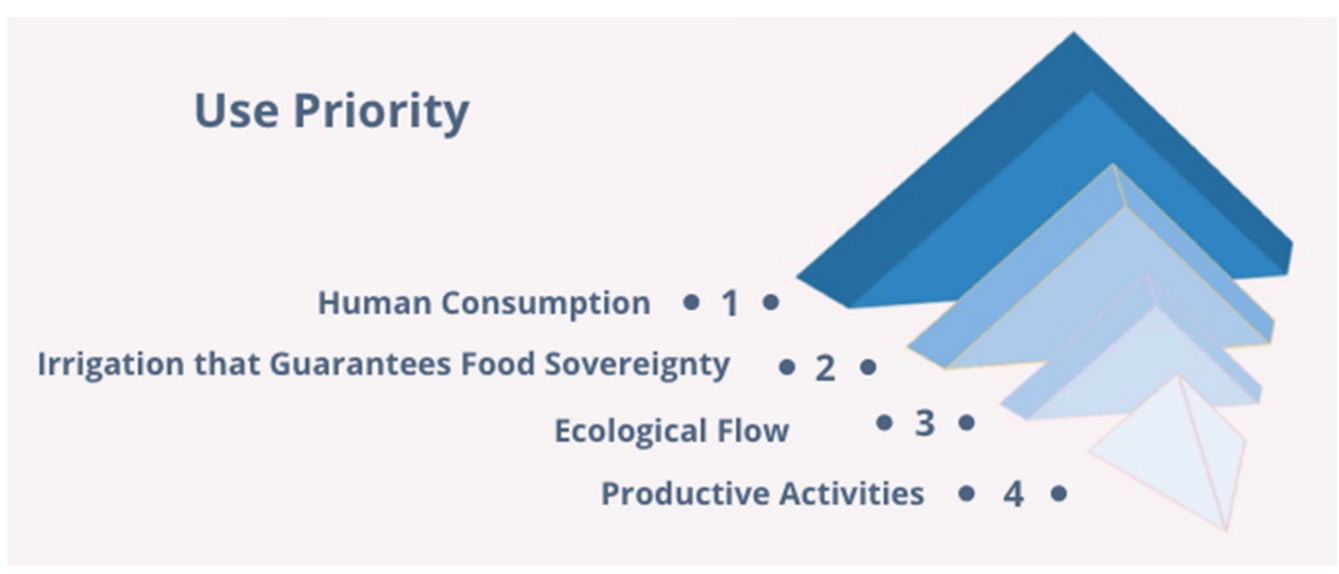

Figure 1. Allocation of water resources in Ecuador based on the analyses of the 2008 Constitution and the Ley Orgánica. Source: Our own elaboration.

3.1.3. TULSMA (The Unified Text of the Ministry of the Environment's Secondary Legislation)

Among the most principal resources for water regulation in Ecuador is the Texto Unificado de la Legislación Secundaria del Ministerio del Ambiente, or "TULSMA" [31]. Table 1 presents a summary of the definitions of each water type, as well as the maximum allowable limits for the various physicochemical and microbial quality parameters applied to them under TULSMA [31].

\subsubsection{NTE INEN 1108: Technical Norms for Potable Water in Ecuador}

In NTE INEN 1108 for Potable Water, or the Norma Técnica Ecuatoriana del Instituto Ecuatoriano de Normalización, the Ecuadorian government specifies the standards for potable drinking water [32]. Limits for organic compounds such as benzene $(<0.01 \mathrm{mg} / \mathrm{L})$, toluene $(<0.7 \mathrm{mg} / \mathrm{L})$, xylene $(<0.5 \mathrm{mg} / \mathrm{L})$, and nitrilotriacetic acid $(<0.2 \mathrm{mg} / \mathrm{L})$, are raised to just below $1 \mathrm{mg} / \mathrm{L}[32,33]$. These restrictions are based on the drinking water guidelines set by the World Health Organization (WHO) [34]. NTE INEN 1108 also allows up to $0.2 \mathrm{mg} / \mathrm{L}$ of nitric acid, again within the limits set by international standards. Similarly, for nonnaturally occurring substances such as benzo[a]pyrene, concentration limits are set to $0.0007 \mathrm{mg} / \mathrm{L}$ in both bodies of legislation [32,34]. 
Table 1. Definitions and regulations of various water types under TULSMA, Libro VI, Anexo I [31].

\begin{tabular}{cc}
\hline Water Type & Definition \\
\hline Water source for human & $\begin{array}{c}\text { Water source whose physical, chemical } \\
\text { and microbial characteristics will be } \\
\text { treated to guarantee their safety for } \\
\text { human consumption }\end{array}$ \\
\end{tabular}

Water for the preservation of of aquatic and wildlife
Water used for preservation of aquatic and wildlife including freshwater

Water Quality Criteria

- $\quad$ Oils and lipids: $0.3 \mathrm{mg} / \mathrm{L}$

- $\quad$ Metals and ions: As and $\mathrm{CN}^{-}: 0.1 \mathrm{mg} / \mathrm{L}$, Ba: $1 \mathrm{mg} / \mathrm{L}, \mathrm{Cd}: 0.02 \mathrm{mg} / \mathrm{L}, \mathrm{Cu}: 2 \mathrm{mg} / \mathrm{L}$, $\mathrm{Cr}(\mathrm{VI}): 0.05 \mathrm{mg} / \mathrm{L}$, Fe: $1 . \mathrm{mg} / \mathrm{L}, \mathrm{Hg}$ : $0.006 \mathrm{mg} / \mathrm{L}, \mathrm{Pb}$ and Se: $0.01 \mathrm{mg} / \mathrm{L}$, $\mathrm{NO}_{3}{ }^{-}: 50 \mathrm{mg} / \mathrm{L}, \mathrm{F}^{-}: 1.5 \mathrm{mg} / \mathrm{L}$

- $\quad$ COD and BOD $5:<4$ and $2 \mathrm{mg} / \mathrm{L}$

- Hydrocarbons: TPH: $0.2 \mathrm{mg} / \mathrm{L}$

- $\mathrm{pH}$ : 6-9

- Tubidity: 100 NTU

- Fecal coliforms: $1000 \mathrm{MPN} / 100 \mathrm{~mL}$

- $\quad$ Oils and lipids: $0.3 \mathrm{mg} / \mathrm{L}$

- Metals and ions: $\mathrm{Al}, \mathrm{Be}$ and $\mathrm{Mn}$ : $0.1 \mathrm{mg} / \mathrm{L}$, As: 0.05, Ba: $1 \mathrm{mg} / \mathrm{L}, \mathrm{Cd}, \mathrm{Pb}$ and Se: $0.001 \mathrm{mg} / \mathrm{L}, \mathrm{Ag}$ and $\mathrm{CN}^{-}$: $0.01 \mathrm{mg} / \mathrm{L}, \mathrm{Co}: 0.2 \mathrm{mg} / \mathrm{L}, \mathrm{Cr}$ : $0.032 \mathrm{mg} / \mathrm{L}, \mathrm{Cu}: 0.005 \mathrm{mg} / \mathrm{L}$, Fe: $0.3 \mathrm{mg} / \mathrm{L}, \mathrm{Hg}: 0.0002 \mathrm{mg} / \mathrm{L}, \mathrm{Ni}$ : $0.025 \mathrm{mg} / \mathrm{L}, \mathrm{Zn}: 0.03 \mathrm{mg} / \mathrm{L}, \mathrm{NO}_{3}{ }^{-}$: $13 \mathrm{mg} / \mathrm{L}$, B: $0.75 \mathrm{mg} / \mathrm{L}$

- $\quad C O D$ and BOD 5 : $<40$ and $20 \mathrm{mg} / \mathrm{L}$

- Hydrocarbons: TPH: $0.5 \mathrm{mg} / \mathrm{L}, \mathrm{PCBs}$ : $1 \mathrm{mg} / \mathrm{L}$, phenols: $0.001 \mathrm{mg} / \mathrm{L}$, chlorophenols and pyrethroid: $0.05 \mathrm{mg} / \mathrm{L}$, organochlorines and organophosphates: $10 \mathrm{mg} / \mathrm{L}$

- $\quad$ Floating material: none

- $\mathrm{pH}: 6-9$

- $\quad$ Oils and lipids: none

- Metals and ions: $\mathrm{Al}: 5 \mathrm{mg} / \mathrm{L}, \mathrm{As}, \mathrm{Be}, \mathrm{Cr}$ and V: $0.1 \mathrm{mg} / \mathrm{L}, \mathrm{B}: 0.75 \mathrm{mg} / \mathrm{L}, \mathrm{Cd}$ : $0.05 \mathrm{mg} / \mathrm{L}, \mathrm{Co}$ and Mo: $0.01 \mathrm{mg} / \mathrm{L}, \mathrm{Cu}$, $\mathrm{Mn}$ and Ni: $0.2 \mathrm{mg} / \mathrm{L}$, Fe and Pb: $5 \mathrm{mg} / \mathrm{L}$, Li: $2.5 \mathrm{mg} / \mathrm{L}, \mathrm{Hg}: 0.001 \mathrm{mg} / \mathrm{L}$, Se: $0.02 \mathrm{mg} / \mathrm{L}, \mathrm{Zn}: 2 \mathrm{mg} / \mathrm{L}, \mathrm{F}: 1 \mathrm{mg} / \mathrm{L}$

Water for agricultural use other related or complementary activitie that establish competent organisms
Floating material: none

- pH: 5

- Fecal coliforms: $1000 \mathrm{MPN} / 100 \mathrm{~mL}$

- Metals and ions: $\mathrm{Al}$ and B: $5 \mathrm{mg} / \mathrm{L}$, As: $0.2 \mathrm{mg} / \mathrm{L}, \mathrm{Cd}$ and $\mathrm{Pb}: 0.05 \mathrm{mg} / \mathrm{L}, \mathrm{Co}$ and Cr: $1 \mathrm{mg} / \mathrm{L}, \mathrm{Cu}: 2 \mathrm{mg} / \mathrm{L}, \mathrm{Hg}: 0.01 \mathrm{mg} / \mathrm{L}$, $\mathrm{NO}_{3}{ }^{-}: 50 \mathrm{mg} / \mathrm{L}, \mathrm{Zn:} 25 \mathrm{mg} / \mathrm{L}$

Water for livestock use Water intended for the trough of animals, as well as other related or complementary activities that establish competent organisms
- TDS: $3000 \mathrm{mg} / \mathrm{L}$

- $\quad$ Fecal coliforms: $1000 \mathrm{MPN} / 100 \mathrm{~mL}$
Water intended for recreational purposes, the use of which includes:

(i) primary contact, such as swimming and diving, including medicinal baths

Water for recreational purposes
- $\quad$ Oils and Lipids: none

- Intestinal nematode parasites: none

- Fecal and total coliforms: 200 and $2000 \mathrm{MPN} / 100 \mathrm{~mL}$

- Hydrocarbons: phenols: $0.002 \mathrm{mg} / \mathrm{L}$

- N:P: $15: 1$

- $\quad$ Floating material: none $\mathrm{pH}$ : 6.5-8.3 (ii) secondary contact, such as in nautical sports and fishing
- $\quad$ Oils and Lipids: none

- Intestinal nematode parasites: none

- Total coliforms: 4000 MPN/100 mL

- N:P: 15:1

- $\quad$ Floating material: none

- $\quad \mathrm{pH}: 6-9$

COD: Chemical oxygen demand; $\mathrm{BOD}_{5}$ : Biochemical oxygen demand measured on day 5; TPH: Total petroleum hydrocarbons; NTU: Nephelometric turbidity unit; MPN: Most probable number; PCBs: polychlorinated biphenyls; TDS: Total dissolved solids. 


\subsubsection{Water Users' Associations (Juntas del Agua)}

At a local level, water users' associations (WUAs) have become increasingly important for water management in Ecuador [12]. Additionally, known as Juntas de Agua, these systems are useful for community unification and self-governance, particularly in rural and impoverished regions where municipal services are limited by the diversity of local needs [35]. Juntas de Agua are divided into two principal types: Juntas de Agua Potable (which determine drinking water allocation) and Juntas de Riego (which determine allocation of water resources for agriculture and general irrigation) $[35,36]$. Each WUA consists of two essential components: the water system itself (including canals, reservoirs, and a network of tubes for delivery) and the management committee (a caretaker, system operator, and a democratically elected board of representatives) [37]. They also rely on a component of community work known as the minga, which involves the labor of volunteers in exchange for water rights [35]. Failure to participate in construction or maintenance work required through the minga can result in the suspension of water access and removal from the decision-making process [37]. Residents who did not participate in the minga are typically required to purchase their water rights through monthly bills [38]. This essential structure thus enables mobilization among rural communities and their leaders, with many influential indigenous politicians gaining recognition and importance primarily through water leadership in their own communities [35].

Nevertheless, financial limitation often leads to internal disputes, necessitating a fourth segment: an external mediator [35]. By determining the legality of these organizations, government mediators may settle local and inter-communal disputes over water allocation, thus integrating local structures into national water management efforts [39]. This has generated resistence among indigenous groups who feel that the government is appropriating the products of their labor [40].

In addition to internal disputes, lack of technical and financial resources limits WUAs' abilities to construct durable water infrastructure [41]. These economic restraints also tend to favor the largest shareholders, including companies and farms whose economic resources afford them greater buying power over water resources [39]. For example, in the Pisque watershed of northern Ecuador, the rise of the rose-export industry has generated tensions due to the increased allocations for large rose-cultivation farms [42]. While locals have forcefully resisted changes to these pricing systems, the use of WUA and minga structures has often offset the need for additional financial resources. In Chambo-Guano, Licto-Guargallá, and Latacunga-Salcedo-Ambato irrigation systems of the Chimborazo and Tungurahua provinces, these customs have allowed organizations to successfully manage water resources with limited funds [43].

Finally, WUAs are often challenged in their ability to communicate and learn from one another, resulting in isolated systems rather than an interconnected network [41]. The recent consolidation of WUAs under SENAGUA (and now the Ministerio del Ambiente y Agua) has therefore focused on improving inter-organizational development and education $[41,44]$. As a result, the incorporation of WUAs into the national system has become an effective component in the effort to address financial, technical, and organizational challenges of water management.

In these ways, Ecuador's focus on equity and sustainability has made the country an example of theoretical success in environmental protection, with resources such as the Amazon and the Galápagos Islands becoming essential points of conservation on both national and international fronts. Nevertheless, financial and technical limitations have limited Ecuador's ability to carry out these procedures. As a result, while Ecuador is theoretically far more environmentally conscious than most nations, its economic and functional challenges have prevented the nation from effectively implementing these measures in practice. 


\subsection{Environmental Analysis of Water Quality Condition in Ecuador}

\subsubsection{Oil Extraction and Processing}

Since 1972, nearly half of Ecuador's gross national income has become dependent on the oil industry, resulting in the exponential expansion of oil activities in areas such as Esmeraldas and the Northern Amazon [45,46]. These activities have important implications for contamination, specifically during storage, transportation, and refinement processes [47]. Primarily, environmental damage is often the result of leakage that occurs in the lining of drilling ponds and along poorly maintained transport lines [48]. Direct oil spills and runoff from drilling operations between 1972 and 1992 have also presented substantial health concerns-Texaco-Chevron alone is estimated to have spilled 18 billion gallons of toxic effluents and crude oil into the Amazon River Basin [15,49]. Finally, the construction of oil processing and extraction facilities and the highways that surround them introduce additional environmental problems in affected communities [10,47].

Recent studies highlight the presence of metallic elements such as Ba and Mo in the Northern Amazonian regions of Orellana and Sucumbíos, where oil extraction and processing is widespread $[46,48]$. Nevertheless, authors emphasize the influence of natural phenomena such as volcanic activity on levels of metallic substances in these areas [15]. In contrast, elevated hydrocarbon levels undeniably indicate the presence of oil activity in Esmeraldas [15,46]. Still, hydrocarbon levels were found within the limits of Ecuadorian legislation for consumption and environmental health, again challenging a destructive view of the oil extraction industry for environmental resources with existing research [46].

These components of crude oil can directly impact human health through three main paths of exposure: direct contact, inhalation of fumes, and consumption of water or affected crops $[47,50]$. Studies show that direct contact with affected water sources is most often realized through swimming and bathing [47]. While these practices are common in remote areas where piped water services are limited, risk-analyses in high-production areas such as Orellana and Sucumbíos find that dermal contact with both soil and water present low threats to human populations [15]. Additionally, over $85 \%$ of measured exposure is attributed to inhalation and ingestion rather skin contact [15]. Consequently, the risk of direct contact from oil pollution may be understood as relatively limited, even among regions most impacted by oil activities.

In contrast, inhalation of particles and consumption of water or affected crops presents an important means of contact for local communities. In a study of San Carlos, high levels of metallic substances and other oil components in drinking water was associated with stomach, liver and other related cancer risks [47]. Higher incidences of childhood leukemia in regions affected by oil production are also frequently cited as potential consequences of prolonged exposure [15].

Finally, the presence of roads and human settlements near oil activity sites raises concerns for delicate and ecologically important environments such as the Amazonian and Andean regions of Ecuador [18]. However, variation in environmental outcomes indicates that there are insufficient causal relationships between oil contamination and health exposure effects [50]. Consequently, more studies are needed to understand the impact of extractive activities on environmental and public health in Ecuador.

\subsubsection{Artisanal and Small-Scale Gold Mining (ASGM) Pollution Factors}

In addition to oil production, artisanal and small-scale gold mining (ASGM) presents substantial risks for water pollution in Ecuador [17]. ASGM is comprised of two types of mining activity, artisanal gold mining (the use of home-made or makeshift equipment to produce and mine gold by local individuals) and small-scale gold mining (a faster method of gold production and refinement that employs simple, mechanical technology), which together account for $85 \%$ of Ecuador's gold production [17]. The promotion of ASGM through buen vivir has increased mining efforts in Ecuador, including in important ecosystems such as the páramos water systems of the Andean highlands [51]. ASGM is 
thus important to the analysis of environmental risks in the country, particularly as mining efforts continue to gain investment from both national and international actors [52].

In recent years, Ecuador has taken aggressive measures to alleviate mercury $(\mathrm{Hg})$ use in ASGM, culminating in the outlaw of $\mathrm{Hg}$ in Ecuador in 2013 [53]. Hg pollution taxes have raised the relative price of $\mathrm{Hg}$ to nearly USD $300 / \mathrm{kg}$ in some highly dependent regions of Ecuador, pressuring miners to shift towards the use of cyanide, a more efficient but highly toxic substance [54]. Due to an increased processing time compared to $\mathrm{Hg}$, cyanide techniques have not been widely developed in Ecuador, often resulting in a lack of safe waste treatment and disposal options [54]. As a result, the dramatic increase in cyanide use that has complimented Ecuador's decrease in $\mathrm{Hg}$ use raises important environmental concerns for ASGM [54].

Recent studies of ASGM nevertheless show that mining has not resulted in widespread contamination of water resources. For example, a study of the Yacumbí river in southeastern Ecuador found that $\mathrm{Hg}$ concentrations were within the limits of both international and domestic requirements [53]. In a study of four additional mining sites in Portovelo-Zaruma, Nabija, Ponce Enriquez, and Santa Rosa, similar patterns were identified, with most metal and metalloid substances well below required limits [55]. While concentrations were low in water samples, the uptake of metals and bioaccumulation of other contaminants were critically identified in the larvae of flies and fish [55]. Researchers tied these findings to a lower availability of large fauna and animal diversity in areas heavily affected by mining activity [55]. Similarly, a study of the Salado Estuary found bioaccumulation of $\mathrm{Hg}$ in mussels and poor quality parameters such as low dissolved oxygen (DO) to be indicative of limited biodiversity and diminished body sizes among local fish populations [56]. Nevertheless, it is important to recognize that fluctuations in $\mathrm{pH}$, temperature, $\mathrm{DO}$, and other parameters are also informed by natural and seasonal variation [57]. For example, in a study of the Napo River Basin, these parameters varied both spatially and temporally as a result of geographical and seasonal changes [57].

Still, the accumulation of metals and other toxic substances is an essential area of concern for LMICs such as Ecuador, where waste is often discharged directly into bodies of water as a result of the high cost of treatment [58]. A study of the Portovelo-Zaruma gold mining center in southern Ecuador found that metallic substances and other components of mine tailings had accumulated substantially in the downstream Puyango river basin of Peru, resulting in an international contamination suit against Ecuador in 2008 [58]. Still, the complexity and interconnected nature of water quality problems implies that additional studies will need to be conducted to evaluate the environmental and public health impacts of ASGM.

\subsubsection{Sewage Discharge and the Impact of Wastewater Treatment on Water Quality}

Over the course of the last decade, the implementation of basic sanitation facilities (including sewer systems, septic tanks, and blind tanks) has increased dramatically, with coverage rising to $97 \%$ for urban areas and $78.9 \%$ for rural areas (with a national average of $91.4 \%$ coverage) in 2014 [59]. Nevertheless, connections to the public sewer system have lagged behind, with a mere $60 \%$ of households connected to the system at a national level in 2014 [59]. In particular, profound divisions between urban and rural accessibility to these public sewer systems remains substantial, with only $22.3 \%$ of rural households connected to the system, as compared to the $77.1 \%$ of urban households with access to public sewage connections [59]. Moreover, despite the recent implementation of wastewater treatment systems in $75 \%$ of municipalities, only $23.3 \%$ of total wastewater effluent is treated at a national level [60]. Due to a lack of financial and technical capacity, these wastewater effluents are regularly discharged as untreated sewage waste into local bodies of water throughout the country (including in the capital city of Quito) [61]. Literature studies therefore highlight the risk of increased contaminants to the receiving ecosystems and to public health. Organic matter and nutrients present in untreated effluents can lead to oxygen depletion and eutrophication in receiving waters, as well to toxicity to fish and 
other aquatic organisms associated with low dissolved oxygen concentrations and exposure to non-ionized ammonia [61]. In a study of viral contamination, researchers found evidence of pathogens within the urban waters of Quito, where only 3\% of sewage waste is treated prior to discharge in surrounding rivers [62,63]. Despite the wide variety of viruses found in the waters, only $9.17 \%$ of identified pathogens were directly impactful to humans [62]. In a recent study of SARS-CoV-2 presence in the rivers surrounding Quito, authors found notably high viral loads of SARS-CoV-2 at all sites in the study [64]. Similarly, a study of Quito's river system found high levels of pollution in 18 rivers and a substantial diversity of microbial contaminants, including two parasites (Cryptosporidium and Giardia spp.) and E. coli pathotypes (enterohemorrhagic E. coli (EHEC), enteroaggregative E. coli (EAEC), enteroinvasive E. coli (EIEC)) [63]. In addition, elevated physico-chemical parameters such as $\mathrm{pH}, \mathrm{COD}$, total suspended solids (TSS) and concentrations of metals such as $\mathrm{Zn}, \mathrm{Cu}, \mathrm{Ni}$, $\mathrm{Pb}, \mathrm{Cd}$, and $\mathrm{Mn}$, as well as $\mathrm{Al}$ and Fe were observed [63]. A separate study in Quito further examined the presence of bio-accumulative chemicals in water, identifying pharmaceuticals such as antidepressants and birth-control as a potential sources of contamination [65]. Nevertheless, these values fell within national and international water quality requirements, providing little evidence of direct human or environmental health consequences [65]. Consequently, studies find significant variability in the impact of microbial, viral, and pathogenic contamination, emphasizing a need for improved wastewater treatment and increased research efforts to protect the long-term health of water resources in Ecuador.

\subsubsection{Agriculture, Pesticides, Aquaculture, and Livestock-Impacted Runoff}

Widespread concerns for pesticide runoff have recently been explored as agricultural production of crops, such as bananas, broccoli, and roses, become essential to the Ecuadorian economy [36,66,67]. In the Guayas River Basin, where cultivation of bananas, rice, maize, and other important products is significant, relatively low concentrations of pesticides were found (with some exceptions in the downstream areas of Babahoyo and Daule) [66]. Researchers nonetheless emphasized the need for technological improvement among farmers, particularly for reducing aerial spraying and direct application of pesticides in rice fields, which increase the intensity of chemical dispersions [66]. The authors further recommended the reduction of specific pesticides with a higher solubility in water (such as cadusafos, butachlor, and pendimethalin) [66].

Fertilizer implementation and runoff from livestock fields has also been studied in regions where manure and other substances may introduce fecal coliforms to watersheds. Two separate studies of water quality in the Yacuambí and Cuenca River Basins of southern Ecuador showed an increasing prevalence of fecal coliforms and $\mathrm{NaCl}$, respectively, in downstream sampling sites $[53,68]$. Both attributed the increasing concentrations to runoff from cattle fields and, in the case of Yacuambí, aquaculture of Tilapia; still, levels were again found within required limits, indicating a lower immediate pollution risk [53,68].

Finally, changes in land use that reduce the amount of natural vegetation may also affect runoff rates [69]. Consequently, reforestation and addition of natural vegetation near riverbanks may help to reduce the flow of materials into bodies of water [69]. In these ways, modified farming and land-use practices will enable Ecuador to promote water safety in agriculturally important regions of the country.

\subsubsection{Domestic Practices on Water Quality}

Finally, some authors highlight the impact of domestic activity on water quality, specifically as a result of storage practices [16,70,71]. In studies of San Cristobal Island in the Galápagos, the Esmeraldas River Basin of northern continental Ecuador, and the Ecuadorian Amazon, researchers identified higher concentrations of E. coli in samples that had been stored for extended periods of time [16,46,70,71]. For example, on San Cristobal Island, researchers found that, despite the high quality of water leaving municipal tap systems, contamination by $E$. coli and other bacterial pollutants persisted when stored in cisterns, roof tanks, and faucets [71]. These authors proposed the implementation 
of communal cistern systems managed by trained municipal workers (in addition to household education programs) as a means to improve water treatment efficacy at a household level [71,72].

\subsection{Economic Dynamics of Water Management in Ecuador}

3.3.1. Payment for Environment/Ecosystem Services (PES), WUA Economics, and New Economic Framework for Water Management

Ecuador's economic framework for water management has undergone substantial changes, beginning with international pressures to decentralize and privatize state resources in the early 1970s through the 1990s [39]. During this period, reform efforts such as the Law of Decentralization and Irrigation Management Transfer (IMT) programs reduced the role of the state in water management [43]. Beginning in the early 2000s, however, discontent and protest of privatization and neoliberal reform resulted in substantial change, particularly for rural and indigenous communities [29]. TULSMA, the Ley Orgánica, and a newly revised constitution became the emblematic documents of these reforms, critically shifting management systems away from privatization $[30,33,73]$. As a result, the economic state of water management has shifted to an authorization model under which the state provides financial and technical support to rural and urban communities [14]. To understand this emerging economic framework, the roles of WUA systems, large economic sectors, and resources such as PES were highlighted in shaping economic outcomes under the authorization approach.

As stated above, the incoherency of many WUA systems with the neoliberal and privatization policies of the 1990s generated substantial resistance to their implementation [44]. For example, purchase or privatization of water resources is incongruent with the minga model of water allocation, under which community members receive access through work rather than payment [35]. In the last three decades, however, water management has reflected the continuously changing patterns of the political and economic systems, resulting in frequent changes to water policy in Ecuador. It is therefore difficult to define a specific model for the Ecuadorian case; however, a combination of communal and private systems inspired by Ostrom's rules for managing common goods could offer a solution to management challenges [74]. In doing so, authorities could rely on the following key principles for water management: definition of specific boundaries, thinking in local terms, participatory decision-making, establishment of sanctions against individuals exploiting common resources, provision of methods for conflict resolution, and incorporation of small systems into larger networks. By adopting these principles, the governance structure might better integrate different actors (such as local governments, indigenous communities, industry agents, academics, etc.) into a larger network for water management in Ecuador [74].

On the other hand, the necessity of funding for infrastructural maintenance and other services has driven the adoption of payment systems in addition to local allocation systems [67]. Following the reforms of the 1990s, PES was proposed as a useful tool for decentralized, flexible protection of water resources [75]. Utilizing direct payment incentives for upstream users, PES aims to increase water's intrinsic economic value among consumers, thereby protecting the resource for downstream use and long-term conservation [76]. In addition, advocates of PES hoped that, by providing economic support to upstream users, environmental conservation could improve the living conditions of rural and impoverished areas [76]. Nevertheless, some authors suggest that these analyses overlook the impact of the existing water values on the success of their implementation [77]. For example, one study in the Chamachán watershed found that most indigenous residents of the area were already aware of the necessity of sustainable practices prior to the implementation of the PES system [76].

More recently, efforts to support water management in Ecuador have focused on the use of water funds [75]. In contrast to PES, water funds utilize voluntary payments aimed at achieving community-oriented conservation goals [78]. These often involve specific projects such as guinea pig farms, ecotourism developments, and reforestation [79]. In 
doing so, water funds attempt to create economic benefits for entire communities rather than individuals [78]. Nevertheless, water fund success in Ecuador may again overlook existing community conservation efforts [79]. For example, in a study of water fund implementation in Cariacu, residents noted that the 2011 ecotourism project to promote alternative incomes and reduce the number of cattle in the páramos ignored existing efforts to move cattle herds out of the area [79]. Similar findings in Oyacachi (where guinea pig farms were promoted in lieu of ecotourism) and Paquiestancia (in which waste cleanup and guinea pig farms were pursued) illustrate the challenges in generating tangible improvements on present conservation efforts among rural communities [79].

\subsubsection{Pollution Taxes}

In addition to the state's legal authority, among the most effective approaches to water regulation in Ecuador has been the implementation of environmental taxes, which require companies and individuals to financially compensate for the pollution they inflict [80]. Based on the principle of "el que contamina, paga" ("he who pollutes, pays"), these constitute a system of income-stratified pollution taxes [80]. Despite their focus on equity in tax levels, many studies show that these practices disproportionately affect poor and marginalized communities, for whom small taxes present a larger economic impact [81]. Many tariffs are also left unpaid and ignored, resulting in the absence of finances required to effectively manage resources [82]. Consequently, while this system is an essential component of pollution regulation, its enforcement is limited in practice.

\subsubsection{The Role of Private Companies}

The literature surrounding economic impacts on water allocation suggests that the rise of floriculture and ASGM, in addition to the persistence of the oil industry under new investment (predominantly from China), has allowed extractive sectors to exert substantial influence within the new framework of water management [51,67].

Primarily, while water privatization companies have historically been a source of contention under the Law of Decentralization, recent legal changes have limited the feasibility of their economic influence. Between the 1970s and 1990s, international pressure to privatize state-managed resources enabled widespread decentralization and, in some cases, privatization of irrigation systems [39]. Persistent challenges to equity and water quality have nevertheless driven efforts to "re-nationalize" regulation, culminating in the formation of SENAGUA (the former state organization for water management) in 2009 [35,83]. By 2014, the Ley Orgánica had formally declared water as a national strategic asset for public use and effectively outlawed privatization [30]. As a result, private companies are largely irrelevant to the implementation of water management policy in Ecuador.

Between the 1970s and 1990s, economic dependence on oil exports allowed companies to exert substantial influence over environmental protection practices, particularly in areas where extraction took place near indigenous lands [11,47]. While many oil companies in the US, Canada, and other countries have faced opposition by local communities, new investment from China has recently renewed international extraction efforts in the country [84]. These new investments have attempted to gain greater support among locals through social welfare and job-oriented programs [84]. Moreover, the adoption of a new system of national debt payment by which oil exports substitute direct payments affords oil companies substantial power in environmental decision-making [84].

More recently, flowers - particularly roses-have become a crucial export in Ecuador [13]. Financial power at both national and local levels enables water-intensive floriculture production to persist even in water-stressed areas [85]. As flower companies frequently occupy larger portions of land with respect to their representation within the population, they often pay higher irrigation and management rates than smaller water users [36]. For example, in the Tabacundo province of northern Ecuador, community users paid USD $0.40 / \mathrm{d}$ for water irrigation in 2016 while large flower companies paid USD 10.00/d in the same year [86]. As a result, these companies exert a disproportionate influence over local 
water allocation, as compared to their size within the population [67]. In a similar manner, the increasing strategic importance of artisanal and small-scale gold mining (ASGM) under buen vivir [52] has afforded mining companies substantial power over the environmental regulation, employing the national development narrative as a means of criminalization in some extreme cases [87].

\subsection{Social Responses to Water-Related Challenges in Ecuador}

\subsubsection{Continued Use of Existing Sources}

As a result of water accessibility concerns, many communities in Ecuador have adopted household coping strategies to secure potable water access. Primarily, both urban and rural households frequently adopt point-based approaches to water procurement, focusing on the treatment of already-available water resources [88]. Water boiling prior to direct consumption is a common strategy for individual households to mitigate the effects of potential pathogens and contaminants [88]. While this strategy is effective for immediate health concerns such as E. coli, water boiling is often used in both at-risk and water-secure regions [88]. For example, one study of water adaptation strategies showed that residents in regions with high water quality (such as the urban suburb of Tena in central Ecuador) as those with lower water quality (such as the rural areas of Atacapi and Chambira) boiled water at comparable rates [20]. As a result, observe that boiling practices are strongly dependent on individual perceptions of water quality in Ecuador, rather than actual water-stress due to contamination.

A second common practice is the use of chlorine treatment, which employs both local and commercial chlorines to reduce pathogen presence [16]. In a study of the effectiveness of chlorine treatment methods among communities in the Esmeraldas province, authors highlighted that, while chlorine was effective in reducing the risk of diarrhea and other health effects, observed water quality often lacked significant parasites $[16,89]$. In contrast, it was more often the use of secondary storage practices that reintroduced bacteria to household water samples [16].

This finding highlights a third important adaptation strategy: the use of cisterns and storage tanks [70]. In areas where water provision is inconsistent or variable, cisterns and storage tanks are used to avoid low pressure or water absence [88]. While storage tanks offer a potential solution to water availability problems, some studies find that these practices increase the risk of contamination during stagnant periods [16,70,71]. As a result, future efforts to improve water quality must incorporate community education programs and a consideration of household-level practices.

\subsubsection{Use of Alternative Sources}

In contrast to boiling, storage, and other immediate responses, some communities seek alternative sources such as bottled water, rainwater collection, or the construction of their own wells. Primarily, the use of bottled water, in addition to sachet (or bagged) water, has grown substantially in recent years, with LMICs experiencing $174 \%$ growth in the bottled water sector between 2008 and 2018 [19]. While bottled water presents an immediate solution to water insecurity problems, some authors find that its high cost excludes some users from the approach [88]. In addition, economically capable households often seek independent well access as an alternative to state-run (or historically privatized) services, enabling both independent access and community-run management [43]. While some areas such as the Canton Eloy Alfaro in northwestern Ecuador present important examples of well-water resources, the high financial costs associated with this approach again limit its feasibility in LMICs such as Ecuador [41,89]. Moreover, some authors emphasize that the absence of high-income households in the tap water market as a result of these two strategies drastically reduces opportunities for infrastructure improvement and maintenance [19].

Some rural and low-income communities of Ecuador have additionally employed rainwater and river water in lieu of expensive wells or bottled water [90]. While few 
studies have accessed the safety or preferability of rainwater to tap water, these approaches present a low-cost solution to water allocation problems [90]. Still, some authors emphasize the time-consuming nature of water collection as a deterrent to the adoption of this approach [88]. In the Amazonian communities of Ecuador, moreover, collection of rainwater increases local households' susceptibility to microbial contamination and mineral depletion [46]. Nevertheless, some authors indicate that elevated contamination levels are the result of extended water storage periods, rather than actual resource contamination [46,71]. Consequently, a need for improved research and education efforts around water quality in access-challenged regions of Ecuador is needed to fully access the risk of these adaptation strategies.

\subsubsection{Protests and Demonstrations}

Finally, while organization and mobilization has proven to be difficult at a global scale, demonstrations and protests regarding water rights have been widely observed in Ecuador [88,91]. Following the adoption of a legal right to water, communities throughout the country were afforded an ideological and legislative framework through which to contest water access [29]. As a result, movements such as the Caminata del Agua of 2014 and localized protests have become important for understanding Ecuadorian water politics [21,91]. For example, Carlos Pérez Guartambel—who changed his name to Yaku (or "water" in Kichwa) after being charged for criminalization of social protest under President Correa's government-became the leader of the indigenous political movement known as Pachacutik following his efforts to protest mining activities near water resources [92].

The protection of the Vilcabamba River in 2011 is often cited as the first effective case of water protection under the 2008 constitution, during which protestors successfully prevented further expansion of an access road that would have increased contamination risks [93]. Through locally focused and identity building movements, many areas of Ecuador-such as the biodiverse region of Yasuni in the Amazon and urban areas of formerly privatized water systems in Guayaquil have similarly illustrated that protest and demonstration for water rights is possible $[9,83,91]$. More recently, the local population in Cuenca celebrated a landmark victory in their popular consultation of mining activity in the southern region of the country [94]. In September of 2020, the constitutional court ruled in favor of their contestation, halting mining activity in the region [95]. These environmental movements are thus critical to a complete understanding of the rise of indigenous political movements, and entail substantial repercussions on the political process [96].

Still, some authors emphasize the need for greater organizational capacity and local input, specifically in the context of constitutional adoptions of indigenous principles and the monopolization of expertise in international dialogues [25]. In the case of Ecuador, adaptations and interpretations of constitutional concepts such as sumak kawsay and buen vivir may allow certain actors to place their interests over others' [93]. This has been the case in many ASGM efforts, under which developmentalist interpretations of buen vivir are used to criminalize anti-mining protests [25,51]. In addition, the isolation of "expert knowledge" among powerful groups and international organizations has limited the participation of marginalized groups at a global level [97]. Consequently, it is important to understand that the current legislative ideology of Ecuador may be used both in the production and limitation of protests.

\section{Conclusions}

In these ways, Ecuador represents an important example of the demonstrative capacity of citizens to protect water resources, as well as of coping strategies and sustainable approaches to water management in geographically and culturally diverse settings. The system of authorization and environmentally conscious water regulation has produced innovative water management solutions despite widespread financial, infrastructural, and geographical challenges. Nevertheless, the influence of extractive industries and limited financial resources has limited the success of these legislative milestones. Conse- 
quently, continued legislative adaptation is required to improve the regulative abilities of the national management system. Moreover, this research suggests that the continued incorporation of local management systems such as WUAs into the larger governance structure may improve allocation and preservation of water in rural or financially challenged regions. In addition, education of water management actors and individual households will be essential to the mitigation of immediate quality concerns, which are often driven by household-level behaviors such as water storage and ineffective treatment approaches. Furthermore, the implementation of wastewater treatment systems and strengthened restrictions on extractive industries will be crucial for preserving ecosystem health near large cities. Finally, this study shows how different groups have used the constitutional rights of nature and culturally specific factors (such as the minga and the principle of sumak kawsay) to protect water resources and expand street-level social protests to national scales. By providing additional research to examine these intersections, Ecuador's current authorization management model for water allocation may continue to improve its efforts to establish long-term water security in the country.

Author Contributions: Conceptualization, S.W., A.M.-M., D.Q., V.O.-H.; methodology, S.W., V.O.-H.; formal analysis, V.O.-H.; investigation, S.W., A.M.-M., D.Q., V.O.-H.; resources, D.Q., V.O.-H.; data curation, S.W.; writing—original draft preparation, S.W.; writing—review and editing, S.W., A.M.-M., D.Q., V.O.-H.; supervision, V.O.-H.; project administration, V.O.-H.; funding acquisition, V.O.-H. All authors have read and agreed to the published version of the manuscript.

Funding: This research was funded by Universidad San Francisco de Quito through grant POA20142021 to Valeria Ochoa-Herrera.

Data Availability Statement: Data are available on request from the authors.

Acknowledgments: We are especially grateful to Mark Giordano for his valuable comments and guidance regarding the structure and direction of this paper.

Conflicts of Interest: The authors declare no conflict of interest.

\section{References}

1. United Nations. Water and Sanitation-United Nations Sustainable Development. Available online: https://www.un.org/ sustainabledevelopment/water-and-sanitation/ (accessed on 1 February 2021).

2. Embid, A.; Martín, L. La Experiencia Legislativa del Decenio 2005-2015 en Materia de Aguas en América Latina; Recursos Naturales E Infraestructura; CEPAL: Santiago, Chile, 2015; pp. 1-55.

3. United Nations. Proceedings of the United Nations Water Conference, Report of the United Nations Water Conference, Mar del Plata, Argentina, 14-15 March 1977.

4. United Nations. General Assembly Convention on the Elimination of All Forms of Discrimination against Women; United Nation: New York, NY, USA, 1979; pp. 1-10.

5. MacPherson, S. The Convention on the Rights of the Child, Social Policy and Administration. 1989. Available online: https: //www.ohchr.org/en/professionalinterest/pages/crc.aspx (accessed on 1 February 2021).

6. United Nations. Rio Declaration on Environment and Development; United Nation: Rio de Janeiro, Brasil, 1992.

7. United Nations. General Comment No. 15: The Right to Water (Arts. 11 and 12 of the International Covenant on Economic, Social and Cultural Rights); United Nation: New York, NY, USA, 2002.

8. Kauffman, C.M.; Martin, P.L. Scaling up Buen Vivir: Globalizing local environmental governance from Ecuador. Global Environ. Politics 2014, 14, 40-58. [CrossRef]

9. Sanchez, E.; Vinueza, R.; Izurieta, X.; Rey, N. Use of muralism to promote awareness about aquatic ecosystems and wise water consumption in northwestern Ecuador. Ocean Coast. Manag. 2020, 190, 5165. [CrossRef]

10. Lessmann, J.; Fajardo, J.; Muñoz, J.; Bonaccorso, E. Large expansion of oil industry in the Ecuadorian Amazon: Biodiversity vulnerability and conservation alternatives. Ecol. Evol. 2016, 6, 4997-5012. [CrossRef] [PubMed]

11. BBC News. Chevron Wins Ecuador Rainforest "Oil Dumping” Case. BBC News. pp. 1-2. Available online: https:/ /www.bbc. com/news/world-latin-america-45455984 (accessed on 8 September 2018).

12. Boelens, R. The Rules of the Game and the Game of the Rules: Normalization and Resistance in Andean Water Control; Wageningen University: Wageningen, The Netherlands, 2008; p. 600.

13. Knapp, G. Mountain agriculture for global markets: The case of greenhouse floriculture in Ecuador. Ann. Am. Assoc. Geogr. 2017, 107, 511-519. [CrossRef]

14. Fernández, N.; Buitrón-Cisneros, R. The right to water and sanitation in Ecuador: Progress, limitations, and challenges. Environ. Justice 2012, 5, 77-81. [CrossRef] 
15. Barraza, F.; Maurice, L.; Uzu, G.; Becerra, S.; López, F.; Ochoa-Herrera, V.; Ruales, J.; Schreck, E. Distribution, contents and health risk assessment of metal (loid)s in small-scale farms in the Ecuadorian Amazon: An insight into impacts of oil activities. Sci. Total Environ. 2018, 622-623, 106-120. [CrossRef]

16. Levy, K.; Anderson, L.; Robb, K.A.; Cevallos, W.; Trueba, G.; Eisenberg, J.N.S. Household effectiveness vs. laboratory efficacy of point-of-use chlorination. Water Res. 2014, 54, 69-77. [CrossRef]

17. Schudel, G.; Kaplan, R.; Adler Miserendino, R.; Veiga, M.M.; Velasquez-López, P.C.; Guimarães, J.R.D.; Bergquist, B.A. Mercury isotopic signatures of tailings from artisanal and small-scale gold mining (ASGM) in southwestern Ecuador. Sci. Total Environ. 2019, 686, 301-310. [CrossRef]

18. Lessmann, J.; Troya, M.J.; Flecker, A.S.; ChrisFunk, W.W.; Guayasamin, J.M.; Ochoa-Herrera, V.; LeRoyPoff, N.N.; Suárez, E.; Encalada, A.C. Validating anthropogenic threat maps as a tool for assessing river ecological integrity in Andean-Amazon basins. PeerJ 2019, 2019, 1-23. [CrossRef]

19. Cohen, A.; Ray, I. The global risks of increasing reliance on bottled water. Nat. Sustain. 2018, 1, 327-329. [CrossRef]

20. Davis, M.J.M.; Gutiérrez, M.L.; Serrano, J. Know your people: Social research and water recycling system design with communities in the Amazon. Procedia Eng. 2016, 145, 1258-1266. [CrossRef]

21. Kolirin, L. "The Trees are my Grandparents": The Ecuador Tribe Trying to Save Its Culture. The Guardian. 16 April 2020, pp. 5-8. Available online: https:/ / www.theguardian.com/world/2020/apr/16/the-trees-are-my-grandparents-the-ecuador-tribe-tryingto-save-its-culture (accessed on 16 April 2020).

22. van den Berg, C.; Danilenko, A. The IBNET Water Supply and Sanitation Performance Blue Book, The International Benchmarking Network for Water and Sanitation Utilities Databook; The World Bank WSP: Washington, DC, USA, 2011.

23. Instituto Geográfico Militar (IGM). Atlas Geográfico de la República del Ecuador; IGM: Quito, Ecuador, 2013.

24. Martínez-Moscoso, A.; Bermeo Cabrera, F. La regulación del saneamiento de las aguas residuales en el Ecuador. In Retos Actuales del Saneamiento de Aguas Residuales. Derivadas Jurídicas, Económicas y Territoriales; Aranzadi Thomson Reuters: Pamplona, Spain, 2020.

25. Boelens, R.; Vos, J.; Perreault, T. Introduction: The Multiple Challenges and Layers of Water Justice Struggles; Cambridge University Press: Cambridge, UK, 2018; ISBN 9781316831847.

26. Asamblea Nacional Constituyente. Constitución Ecuatoriana del 2008; República del Ecuador: Montecristi, Ecuador, 2008.

27. Martínez-Moscoso, A.; Feijó, V.G.A.; Silva, T.V. The vital minimum amount of drinking water required in Ecuador. Resources 2018, 7, 15. [CrossRef]

28. Martínez-Moscoso, A.; Larson, R. Forestry management and water law: Comparing Ecuador and Arizona. Water Int. 2019, 44, 337-353. [CrossRef]

29. Tanasescu, M. The rights of nature in Ecuador: The making of an idea. Int. J. Environ. Stud. 2013, 70, 846-861. [CrossRef]

30. Asamblea Nacional. Ley Orgánica de Recursos Hídricos, Usos, y Aprovechamiento del Agua; República del Ecuador: Quito, Ecuador, 2014.

31. Ministerio del Ambiente del Ecuador. TULSMA—-097-A: Texto Unificado de Legislación Secundaria del Ministerio del Ambiente: Norma de Calidad Ambiental y de Descarga de Efluentes al Recurso Agua; MAE: Quito, Ecuador, 2015.

32. República del Ecuador. NTE INEN 1108 Agua Potable; INEN: Quito, Ecuador, 2011.

33. República del Ecuador. Norma de Calidad Ambiental y de Descarga de Efluentes: Recurso Agua; MAE: Quito, Ecuador, 2015.

34. World Health Organization. Guidelines for Drinking-Water Quality; World Health Organization: Geneva, Switzerland, 2017; Volume 1, p. 307. [CrossRef]

35. Armijos, T.M. "They cannot come and impose on us": Indigenous autonomy and resource control through collective water management in Highland Ecuador. Radic. Hist. Rev. 2013, 116, 86-103. [CrossRef]

36. Partridge, T. Water justice and food sovereignty in Cotopaxi, Ecuador. Environ. Justice 2016, 9, 49-52. [CrossRef]

37. Hinojosa, L.; Villegas, W.G.; Muñoz, P.A. Exploring water security and water demand determinants in rural areas. The case of canton Cotacachi in Ecuador. Water Resour. Rural Dev. 2017, 10, 22-32. [CrossRef]

38. Hoogesteger, J. Social capital in water user organizations of the ecuadorian highlands. Hum. Organ. 2013, 72, 347-357. [CrossRef]

39. Cremers, L.; Ooijevaar, M.; Boelens, R. Institutional reform in the Andean irrigation sector: Enabling policies fpr strengthening local rights and water management. Nat. Resour. Forum 2005, 29, 37-50. [CrossRef]

40. Acosta-Maldonando, M.E.; Basani, M.; Solís, H. Prácticas y Saberes en la Gestión Comunitaria del Agua para Consumo Humano y Saneamiento en las Zonas Rurales de Ecuador; Banco Interamericano de Desarrollo: Quito, Ecuador, 2019.

41. Kayser, G.L.; Amjad, U.; Dalcanale, F.; Bartram, J.; Bentley, M.E. Drinking water quality governance: A comparative. Environ. Sci. Policy 2015, 48, 186-195. [CrossRef]

42. Mena-Vásconez, P.; Boelens, R.; Vos, J. Food or flowers? Contested transformations of community food security and water use priorities under new legal and market regimes in Ecuador's highlands. J. Rural Stud. 2016, 44, 227-238. [CrossRef]

43. Hoogesteger, J.; Tiaguaro-Rea, Y.; Rap, E.; Hidalgo, J.P. Scalar politics in sectoral reforms: Negotiating the implementation of water policies in Ecuador (1990-2008). World Dev. 2017, 98, 300-309. [CrossRef]

44. Hoogesteger, J. Democratizing water governance from the grassroots: The development of interjuntas-chimborazo in the Ecuadorian Andes. Hum. Organ. 2012, 71, 76-86. [CrossRef]

45. Center for Economic and Social Rights Rights Violations in the Ecuadorian Amazon. The human consequences of oil development. Health Hum. Rights 1994, 1, 82-100. [CrossRef] 
46. Maurice, L.; López, F.; Becerra, S.; Jamhoury, H.; Le Menach, K.; Dévier, M.H.; Budzinski, H.; Prunier, J.; Juteau-Martineau, G.; Ochoa-Herrera, V.; et al. Drinking water quality in areas impacted by oil activities in Ecuador: Associated health risks and social perception of human exposure. Sci. Total Environ. 2019, 690, 1203-1217. [CrossRef]

47. Ramirez, M.I.; Arevalo, A.P.; Sotomayor, S.; Bailon-Moscoso, N. Contamination by oil crude extraction-Refinement and their effects on human health. Environ. Pollut. 2017, 231, 415-425. [CrossRef]

48. Capparelli, M.V.; Moulatlet, G.M.; Abessa, D.M.d.S.; Lucas-Solis, O.; Rosero, B.; Galarza, E.; Tuba, D.; Carpintero, N.; OchoaHerrera, V.; Cipriani, I. An integrative approach to identify the impacts of multiple metal contamination sources on the Eastern Andean foothills of the Ecuadorian Amazonia. Sci. Total Environ. 2020, 709, 136088. [CrossRef]

49. Climatewire. Ecuador Oil Spill Fouls Amazon Tributary; Climatewire: Arlington, VA, USA, 2013; Volume 1.

50. Coronel-Vargas, G.; Au, W.W.; Izzotti, A. Public health issues from crude-oil production in the Ecuadorian Amazon territories. Sci. Total Environ. 2020, 719, 134647. [CrossRef]

51. Shade, L. Sustainable development or sacrifice zone? Politics below the surface in post-neoliberal Ecuador. Extr. Ind. Soc. 2015, 2, 775-784. [CrossRef]

52. Avc1, D.; Fernández-Salvador, C. Territorial dynamics and local resistance: Two mining conflicts in Ecuador compared. Extr. Ind. Soc. 2016, 3, 912-921. [CrossRef]

53. Villa-Achupallas, M.; Rosado, D.; Aguilar, S.; Galindo-Riaño, M.D. Water quality in the tropical Andes hotspot: The Yacuambi river (southeastern Ecuador). Sci. Total Environ. 2018, 633, 50-58. [CrossRef]

54. Gonçalves, A.O.; Marshall, B.G.; Kaplan, R.J.; Moreno-Chavez, J.; Veiga, M.M. Evidence of reduced mercury loss and increased use of cyanidation at gold processing centers in southern Ecuador. J. Clean. Prod. 2017, 165, 836-845. [CrossRef]

55. Lane, S. Environmental impact of small-scale and artisanal gold mining in southern Ecuador: Implications for the setting of environmental standards and for the management of small-scale mining operations. Ambio 2009, 29, 484-491. [CrossRef]

56. Calle, P.; Monserrate, L.; Medina, F.; Calle-Delgado, M.; Tirapé, A.; Montiel, M.; Ruiz-Barzola, O.; Cadena, O.A.; Dominguez, G.A.; Alava, J.J. Mercury assessment, macrobenthos diversity and environmental quality conditions in the Salado Estuary (Gulf of Guayaquil, Ecuador) impacted by anthropogenic influences. Mar. Pollut. Bull. 2018, 136, 365-373. [CrossRef]

57. Alexiades, A.V.; Encalada, A.C.; Lessmann, J.; Guayasamin, J.M. Spatial prediction of stream physicochemical parameters for the Napo River Basin, Ecuador. J. Freshw. Ecol. 2019, 34, 249-263. [CrossRef]

58. Delgado, J.; Barba-Brioso, C.; Ayala, D.; Boski, T.; Torres, S.; Calderón, E.; López, F. Remediation experiment of Ecuadorian acid mine drainage: Geochemical models of dissolved species and secondary minerals saturation. Environ. Sci. Pollut. Res. 2019, 26, 34854-34872. [CrossRef]

59. Secretaria del Agua; Agencia de Regulación y Control del Agua; Ministerio del Ambiente; Ministerio de Salud Pública; Agencia Nacional de Regulación Control y Vigilancia Sanitaria. Estrategia Nacional de Calidad del Agua (ENCA) 2016-2030 Ecuador; SENAGUA; ARCA; MAE; AECSA: Quito, Ecuador, 2016.

60. Rodríguez, P.P. Inventario de Sistemas de Tratamiento de Aguas Residuales de Ecuador; BID: Quito, Ecuador, 2020.

61. Benítez, M.B.; Champagne, P.; Ramos, A.; Torres, A.F.; Ochoa-Herrera, V. Wastewater treatment for nutrient removal with Ecuadorian native microalgae. Environ. Technol. 2019, 40, 2977-2985. [CrossRef]

62. Guerrero-Latorre, L.; Romero, B.; Bonifaz, E.; Timoneda, N.; Rusiñol, M.; Girones, R.; Rios-Touma, B. Quito's virome: Metagenomic analysis of viral diversity in urban streams of Ecuador's capital city. Sci. Total Environ. 2018, 645, 1334-1343. [CrossRef]

63. Borja-Serrano, P.; Ochoa-Herrera, V.; Maurice, L.; Morales, G.; Quilumbaqui, C.; Tejera, E.; Machado, A. Determination of the microbial and chemical loads in rivers from the Quito capital province of Ecuador (Pichincha)—A preliminary analysis of microbial and chemical quality of the main rivers. Int. J. Environ. Res. Public Health 2020, 17, 5048. [CrossRef]

64. Guerrero-Latorre, L.; Ballesteros, I.; Villacrés-Granda, I.; Granda, M.G.; Freire-Paspuel, B.; Ríos-Touma, B. SARS-CoV-2 in river water: Implications in low sanitation countries. Sci. Total Environ. 2020, 743, 832. [CrossRef]

65. Voloshenko-Rossin, A.; Gasser, G.; Cohen, K.; Gun, J.; Cumbal-Flores, L.; Parra-Morales, W.; Sarabia, F.; Ojeda, F.; Lev, O. Emerging pollutants in the Esmeraldas watershed in Ecuador: Discharge and attenuation of emerging organic pollutants along the San Pedro-Guayllabamba-Esmeraldas rivers. Environ. Sci. Process. Impacts 2015, 17, 41-53. [CrossRef] [PubMed]

66. Deknock, A.; De Troyer, N.; Houbraken, M.; Dominguez-granda, L.; Nolivos, I.; Van Echelpoel, W.; Anne, M.; Forio, E.; Spanoghe, P.; Goethals, P. Distribution of agricultural pesticides in the freshwater environment of the Guayas river basin (Ecuador). Sci. Total Environ. 2019, 646, 996-1008. [CrossRef] [PubMed]

67. Mena-Vásconez, P.; Vincent, L.; Vos, J.; Boelens, R. Fighting over water values: Diverse framings of flower and food production with communal irrigation in the Ecuadorian Andes. Water Int. 2017, 42, 443-461. [CrossRef]

68. Jerves-Cobo, R.; Lock, K.; Van Butsel, J.; Pauta, G.; Cisneros, F.; Nopens, I.; Goethals, P.L.M. Biological impact assessment of sewage outfalls in the urbanized area of the Cuenca River basin (Ecuador) in two different seasons. Limnologica 2018, 71, 8-28. [CrossRef]

69. Iñiguez-Armijos, C.; Sánchez, J.; Villareal, M.; Aguilar, S.; Rosado, D. Effects of bathing intensity, rainfall events, and location on the recreational water quality of stream pools in southern Ecuador. Chemosphere 2020, 243, 5442. [CrossRef]

70. Gerhard, W.A.; Choi, W.S.; Houck, K.M.; Stewart, J.R. Water quality at points-of-use in the Galapagos Islands. Int. J. Hyg. Environ. Health 2017, 220, 485-493. [CrossRef]

71. Grube, A.M.; Stewart, J.R.; Ochoa-Herrera, V. The challenge of achieving safely managed drinking water supply on San Cristobal island, Galápagos. Int. J. Hyg. Environ. Health 2020, 228, 113547. [CrossRef] 
72. Brown, J.; Clasen, T. High adherence is necessary to realize health gains from water quality interventions. PLoS ONE 2012, 7, 1-10. [CrossRef]

73. Vanhulst, J.; Beling, A.E. Post-Eurocentric sustainability governance. In Routledge Handbook of Global Sustainability Governance; Routledge Handbook of Global Sustainability Governance: Milton, UK, 2019. [CrossRef]

74. Ostrom, E. The Future of the Commons: Beyond Market Failure and Government Regulation; The Institute of Economic Affairs: London, UK, 2012.

75. Hayes, T.; Murtinho, F.; Cárdenas-Camacho, L.M.; Crespo, P.; McHugh, S.; Salmerón, D. Can conservation contracts co-exist with change? Payment for ecosystem services in the context of adaptive decision-making and sustainability. Environ. Manag. 2014, 55, 69-85. [CrossRef]

76. De Francisco, J.C.R.; Boelens, R. Payment for environmental services and power in the Chamachán Watershed, Ecuador. Hum. Organ. 2014, 73, 351-362. [CrossRef]

77. Boelens, R.; Hoogesteger, J.; De Francisco, R.J.C. Commoditizing water territories: The clash between Andean water rights cultures and payment for environmental services policies. Capital. Nat. Soc. 2014, 25, 84-102. [CrossRef]

78. Kauffman, C.M. Financing watershed conservation: Lessons from Ecuador's evolving water trust funds. Agric. Water Manag. 2014, 145, 39-49. [CrossRef]

79. Joslin, A.J. Unpacking 'success': Applying local perceptions to interpret influences of water fund payments for ecosystem services in the Ecuadorian Andes. Soc. Nat. Resour. 2019, 32, 617-637. [CrossRef]

80. Moscoso, M.A. The new environmental framework in Ecuador. Study of the Organic Environmental Code. Actual. Jurídica Ambient. 2019, 90, 1-32.

81. Roa-García, M.C. Equity, efficiency and sustainability in water allocation in the andes: Trade-offs in a full world. Water Altern. 2014, 7, 298-319.

82. Swing, K.; Sempértegui, L. Problems enforcing Ecuador ecology law. Nature 2012, 491, 40. [CrossRef]

83. Whitehead, F. Ecuadorians tired of Waiting for a Cleanup of Guayaquil's Filthy Waters. The Guardian. 26 May 2016 , pp. 1-4. Available online: https://www.theguardian.com/global-development/2016/may/26/ecuador-veolia-clean-up-guayaquilwater-sanitation-pollution (accessed on 26 May 2016).

84. Ray, R.; Chimienti, A. A. A Line in the Equatorial Forests: Chinese investment and the environmental and social impacts of extractive industries in Ecuador. In China and Sustainable Development in Latin America; Ray, R., Gallagher, K., López, A., Sanborn, C., Eds.; Anthem Press: London, UK, 2017; pp. 1-51.

85. Damonte, G.H. The constitution of hydrosocial power: Agribusiness and water scarcity in Ica, Peru. Ecol. Soc. 2019, 24, 221. [CrossRef]

86. Hidalgo, J.P.; Boelens, R.; Vos, J. De-colonizing water. Dispossession, water insecurity, and Indigenous claims for resources, authority, and territory. Water Hist. 2017, 9, 67-85. [CrossRef]

87. Valladares, C.; Boelens, R. Mining for mother Earth. Governmentalities, sacred waters and nature's rights in Ecuador. Geoforum 2019, 100, 68-79. [CrossRef]

88. Majuru, B.; Suhrcke, M.; Hunter, P.R. How do households respond to unreliable water supplies? A systematic review. Int. J. Environ. Res. Public Health 2016, 13, 1222. [CrossRef]

89. Bhavnani, D.; Goldstick, J.E.; Cevallos, W.; Trueba, G.; Eisenberg, J.N.S. Synergistic effects between rotavirus and coinfecting pathogens on diarrheal disease: Evidence from a community-based study in northwestern Ecuador. Am. J. Epidemiol. 2012, 176, 387-395. [CrossRef] [PubMed]

90. Lee, G.O.; Whitney, H.J.; Blum, A.G.; Lybik, N.; Cevallos, W.; Trueba, G.; Levy, K.; Eisenberg, J.N. Household coping strategies associated with unreliable water supplies and diarrhea in Ecuador, an upper-middle-income country. Water Res. 2019, 11, 1-42. [CrossRef] [PubMed]

91. Picq, M. Is Water Still a Human Right in Ecuador? Upside Down World. 2014, pp. 1-4. Available online: https:/ / upsidedownworld. org/archives/ecuador/is-water-still-a-human-right-in-ecuador (accessed on 1 February 2021).

92. Martínez-Moscoso, A.; Abril-Ortíz, A.; Bermeo-Cabrera, F. Diálogo Sobre la Protección Jurisdiccional de los Derechos a la Salud, Educación, Trabajo, Seguridad Social y Medio Ambiente Sano en Países de América Latina; Centro de Estudios de Justicia de las Américas (CEJA) y GIZ: Santiago de Chile, Chile, 2019; ISBN 9789568491697.

93. Dupuits, E.; Baud, M.; Boelens, R.; de Castro, F.; Hogenboom, B. Scaling up but losing out? Water commons' dilemmas between transnational movements and grassroots struggles in Latin America. Ecol. Econ. 2020, 172, 6625. [CrossRef]

94. Bnamericas. Ecuador Activists Want Mining Consultations to "Rain Down"; BnAmericas: Santiago, Chile, 2020.

95. Primicias. Corte Constitucional da Paso a Consulta Minera en Cuenca; Primicias: Quito, Ecuador, 2020.

96. Martínez-Moscoso, A.; Alarcón-Pena, P.; Coronel, J.; Calle, Á.; Bermeo, F.; Carpio, C. Tutela de Los Derechos de la Naturaleza y el Ambiente Sano; Instituto de Investigaciones Jurídicas, Colego de Jurisprudencia, USFQ: Quito, Ecuador, 2021.

97. Zwarteveen, M.Z.; Boelens, R. Defining, researching and struggling for water justice: Some conceptual building blocks for research and action. Water Int. 2014, 39, 143-158. [CrossRef] 